\title{
Physical Properties Evaluation of Calcium Silicate Cement Board Based on Indonesia Local Kaolin
}

\author{
Nurhidayati $^{1 *}$, R Y Lestari ${ }^{1}$, I D G P Prabawa ${ }^{1}$, N Nurmilatina ${ }^{1}$, F E Hasfianti ${ }^{1}$, S \\ Hamdi $^{1}$
}

\author{
${ }^{I}$ The Institution of Research and Standardization of Industry Banjarbaru (Balai Riset dan Standardisasi Industri \\ Banjarbaru) Indonesia \\ *Corresponding author. Email: nurhidayati.muan@gmail.com
}

\begin{abstract}
In recent year, cement board including calcium silicate cement board has attracted significant attention from researchers and industries as a building component for more affordable housing. In general, the raw materials for calcium silicate cement board consist of silica sand, cement, pulp (cellulose), and clay. However, some raw materials have been imported such as pulp and clay. Kaolin Belitung is considered the most promising substitute for imported clay. This research is aim at evaluating the physical properties from calcium silicate cement board production based on Kaolin Belitung. Both of Kaolin Belitung and imported clay cement boards were tested for their physical (dimension, density, water absorption, waterproof, porosity, and weather resistance) and mechanical (bending strength) properties. Scanning Electron Microscopy (SEM) analysis was performed to determine the surface morphology of the cement boards. The results revealed that the calcium silicate cement board made from Kaolin Belitung has comparable compressive strength $(\sim 130,16 \mathrm{~kg} / \mathrm{cm} 2)$, water absorption $(\sim 13,1 \%)$, and porosity $(\sim 34,7 \%)$. It also gave good results at dimension, waterproof and weather resistance characterization. These properties suggest that Kaolin Belitung may be used as imported clay substitution in the production of calcium silicate cement board.
\end{abstract}

\section{Keywords: Calcium Silicate Cement Board, Kaolin, Weather Resistance, Waterproof}

\section{INTRODUCTION}

In recent year, cement board including calcium silicate cement board has attracted significant attention from researchers and industries as a building component for more affordable housing. Calcium silicate board has been applied in many sectors due to its good performance with sound insulation, moisture resistance, flame retardant and lightweight [1].

In general, the raw materials for calcium silicate cement board consist of inorganic material such as silica sand, Portland cement, pulp (cellulose), clay and water. It is widely used as an alternative to asbestos and gyp-sum cement board. Asbestos cement board could give health problem to the building resident, while gypsum could easily dissolve in water so that it could use as outdoor building components. Formerly, calcum silicate cement board was used for indoor partition and ceiling but nowadays, calcium silicate cement board also used as wall façade [2].

Ordinary Portland cement (OPC) as calcium material, reactive quartz sand as siliceous material, and wood fiber or others fiber as reinforcing materials are commonly used as raw material of calcium silicate cement board [1]. Silica sand serves as a source of strength in cement board products. The composition of the sand used includes $90-95 \%$ silica, $0-3 \%$ aluminum oxide, $0-1 \%$ calcium oxide and $0-2 \%$ magnesium oxide. Cement functions as an adhesive. Pulp or cellulose serves as a source of strength and flexibility. The pulp used has a high cellulose content and long fiber. Solid waste (sludge) can also be used as a substitute for pulp in the manufacture of cement boards. Clay serves as strength, increasing water resistance, fire resistance and plasticity in cement board products. 
However, some raw materials of cement board have been imported such as pulp and clay. In 2019, Indonesia imported $57,639,850 \mathrm{~kg}$ of clay or equivalent to US \$ $38,746,760$. On the other hand, Indonesia, especially the province of Bangka Belitung, has kaolin resources of $376,687,532$ tons. Therefore, Belitung kaolin has the potential to become a substitute for imported clay and considered the most promising substitute for imported clay. [3][4] This research is aim at evaluating the physical properties from calcium silicate cement board production based on Kaolin Belitung.

\section{METHODS}

\subsection{Materials}

The materials of cement board produced in this study were cement, silica sand, pulp and clay. Silica sand was obtained from Palangkaraya. Imported pulp and waste pulp Kraft were obtained from Canada and New Zealand. Imported clay was obtained from Taiwan. Local clay that used in this study was kaolin Belitung from PT. Aneka Kaolin. The equipment used in this study was machines from PT. SNI factory that located at South Kalimantan. The machines consist of drying machine for sand, milling machine including ball mill and vertical mill, Hydra pulper machine, mixer, Hatschek machine, stacking machine, and autoclave.

\subsection{Method}

Cement board either based on Kaolin Belitung or imported clay was produced in PT. SNI factory, South Kalimantan. It went through raw material preparation, sheet making process and drying process.

Silica sand undergo drying process in the sand drying machine until reach a certain moisture content of \pm $3 \%$ before proceeded to a sand grinding machine. There were 2 types of sand grinding machines, namely ball mill and vertical mill. The milling tool used to grinding silica sand up to 325 mesh size. Pulp obtained from industrial paper and waste pulp Kraft (WPK) was prepared with Hydra machine. Hydra was a tool for grinding paper into pulp with a degree of scoop ringler ( $\left.{ }^{\circ} \mathrm{SR}\right)$ and a concentration in accordance with the required production standards.

Cement board produced in two batches. Silica sand, cement, pulp and clay were mixed together. $2,07 \%$ of clay were used in this cement board composition. The mixture went into sheet making process with Hatschek machine. The base of the Hatschek machine consisted of a cylindrical filter drum which rotated and contacted with cement board mixture. After the sheet was formed, the process continued to the stacking machine that checked the thickness and cut the sheet according to size. Cement board then put into autoclave for drying process.

Both of Kaolin Belitung and imported clay cement boards were tested for their physical (dimension, density, water absorption, waterproof, porosity, and weather resistance) and mechanical (bending strength) properties. Bending strength, density, water absorption and porosity were tested in PT. SNI factory in accordance with SNI 7705:2011. Dimension, waterproof and weather resistance parameter were tested in IUB2T DKI Jakarta laboratory in accordance with SNI 1027:2015. Surfaces morphology of the cement boards was investigated using scanning electron microscope (SEM) JEOL JSM6360LA from Geology Laboratories PSG.

\section{RESULTS AND DISCUSSION}

\subsection{Physical Characterization of Cement Board}

Calcium silicate cement board sample are prepared using silica sand, cement, pulp and clay. Clay worked as source of strength and plasticity that could increase waterproof and fire resistant properties [3].

In this study, cement board produced in two batches with slightly different composition. Clay composition for either batch 1 and batch 2 remain the same at 2,07\%. Cement/Silica sand ratio of cement board from batch 1 and batch 2 were $1 / 1,3$ and 1/1,6. The difference in cement/silica sand ratio gave different mechanical properties to cement board products. The result of mechanical characterization of cement board is shown in Table 1 .

Table 1. Mechanical characterization of cement board.

\begin{tabular}{|l|c|c|c|c|}
\hline \multirow{4}{*}{ Parameter } & \multicolumn{4}{|c|}{ Cement board sample } \\
\cline { 2 - 5 } & Kaolin Belitung (KB) & \multicolumn{2}{|c|}{ Imported Clay (IC) } \\
\cline { 2 - 5 } & $\begin{array}{c}\text { Batch 1 } \\
\text { (B1) }\end{array}$ & $\begin{array}{c}\text { Batch 2 } \\
\text { (B2) }\end{array}$ & $\begin{array}{c}\text { Batch 1 } \\
\text { (B1) }\end{array}$ & $\begin{array}{c}\text { Batch 2 } \\
\text { (B2) }\end{array}$ \\
\hline $\begin{array}{l}\text { Bending } \\
\begin{array}{l}\text { Strength } \\
\left(\mathrm{kg} / \mathrm{cm}^{2}\right)\end{array}\end{array}$ & 130,16 & 102,82 & 123,95 & 104,52 \\
\hline
\end{tabular}

As shown in Table 1, the bending strength from cement board based on kaolin Belitung gave the similar results when compared to the bending strength from cement board based on imported clay. Kaolin Belitung could act the same way imported clay acted in cement board mixture. This is happening because the cement board source of strength is mainly come from the cement matrix. According to Hossain (2019), calcium silicate hydrate $(\mathrm{C}-\mathrm{S}-\mathrm{H})$ which is main hydration product of cement board is responsible to cement board strength [5]. Mingxu (2017) said that the good performance of calcium silicate cement board is assign to the generation of tobermorite (Ca5Si6O17.5H2O) [1]. Tobermorite is a 
type of crystalline calcium silicate hydrate that synthesized by the reaction in the $\mathrm{CaO}-\mathrm{SiO} 2-\mathrm{H} 2 \mathrm{O}$ system. Quartz sand reacts with $\mathrm{Ca}(\mathrm{OH}) 2$ leading to the hydration of silicate mineral and eventually generate tobermorite. Tobermorite conduct low density and better thermal insulation properties that can be widely used in building materials. Moreover, the difference shown between batch 1 and batch 2 were come from the difference of cement/silica sand ratio. Higher ratio increasing the possibility of tobermorite formation in CSH system and eventually gave the higher bending strength value.

\subsection{Physical Characterization of Cement Board}

Table 2. Water absorption, density and porosity testing result of cement board.

\begin{tabular}{|c|c|c|c|c|}
\hline \multirow{3}{*}{ Parameter } & \multicolumn{4}{|c|}{ Cement board sample } \\
\hline & \multicolumn{2}{|c|}{$\begin{array}{l}\text { Kaolin Belitung } \\
\text { (KB) }\end{array}$} & \multicolumn{2}{|c|}{ Imported Clay (IC) } \\
\hline & $\begin{array}{c}\text { Batch 1 } \\
\text { (B1) }\end{array}$ & $\begin{array}{c}\text { Batch } 2 \\
\text { (B2) }\end{array}$ & $\begin{array}{c}\text { Batch 1 } \\
\text { (B1) }\end{array}$ & $\begin{array}{c}\text { Batch } 2 \\
\text { (B2) }\end{array}$ \\
\hline $\begin{array}{l}\text { Water ab- } \\
\text { sorption (\%) }\end{array}$ & 13,1 & 12,9 & 13,4 & 10,9 \\
\hline $\begin{array}{l}\text { Density } \\
\left(\mathrm{g} / \mathrm{cm}^{3}\right)\end{array}$ & 1,30 & 1,21 & 1,32 & 1,21 \\
\hline Porosity (\%) & 34,7 & 40,9 & 34,4 & 39,1 \\
\hline
\end{tabular}

As shown in Table 2, the density and porosity from cement board based on kaolin Belitung gave the similar results when compared to the density and porosity from cement board based on imported clay. The density and porosity of calcium silicate boards influenced the performance and applications of the material. Lower porosity is one of a way to increase strength because porosity could induce several promising sites for producing cracks and its spreading [5].

However, the water absorption testing result showed that the cement board made from kaolin Belitung had higher water absorption, with a difference of about $2 \%$. This can be influenced by the nature of kaolin which is easier to bind water than illite (imported clay).

The results of the waterproofing test between the cement boards made from kaolin Belitung and imported clay were not significantly different. Both showed good results, namely no water droplets. The waterproof test applied to sheets with a thickness of more than $5.0 \mathrm{~mm}$, but it still showed good result with the cement boards from this study that had $3.5 \mathrm{~mm}$ thickness. The results of the weather resistance test between the kaolin Belitung cement boards and imported clay cement boards were not significantly different. Both of them did not show any cracks/breaks after going through performance against weather conditions (hot and rainy) through a simulation of alternating water and heating treatments in a laboratory environment.

All testing such as bending strength, water absortion, density, waterproof, weather resistance on cement boards aims to show that the cement boards made from kaolin Belitung did have good quality. Tests were also carried out based on SNI 1027-2015 and SNI 7705:2011. Tests for waterproofing and weather resistance are also important because they are in accordance with the weather conditions in Indonesia. The results of the cement board test results showed that there was no significant difference with cement boards made from imported

Table 3. Dimension, waterproof and weather resistance testing result of cement board

\begin{tabular}{|c|c|c|c|c|c|}
\hline \multirow{2}{*}{ Size, mm } & \multirow{2}{*}{$\begin{array}{c}\text { Testing } \\
\text { Parameter }\end{array}$} & \multicolumn{2}{|c|}{ Cement Board made from kaolin Belitung } & \multicolumn{2}{|c|}{$\begin{array}{c}\text { Cement Board made from imported } \\
\text { clay }\end{array}$} \\
\hline & & Testing Result & SNI 1027-2015 & Testing Result & SNI 1027-2015 \\
\hline \multirow{8}{*}{$\begin{array}{c}1000 \times 1000 x \\
3,5\end{array}$} & Edge cut & Straight, flat & Straight, flat & Straight, flat & Straight, flat \\
\hline & Shape & Rectangle & Rectangle & Rectangle & Rectangle \\
\hline & Surface & Smooth & Smooth & Smooth & Smooth \\
\hline & Defect & None & None & None & None \\
\hline & Colour & Original & $\begin{array}{l}\text { Original or with lay- } \\
\text { ered of colour }\end{array}$ & Original & $\begin{array}{l}\text { Original or with } \\
\text { layered of colour }\end{array}$ \\
\hline & $\begin{array}{c}\text { Sheet } \\
\text { properties }\end{array}$ & Stiff & Stiff & Stiff & Stiff \\
\hline & Waterproof & Good & $\begin{array}{l}\text { No water drops, } \\
\text { thickness }>5 \mathrm{~mm}\end{array}$ & Good & $\begin{array}{l}\text { No water drops, } \\
\text { thickness }>5 \mathrm{~mm}\end{array}$ \\
\hline & $\begin{array}{l}\text { Weather } \\
\text { resistance }\end{array}$ & $\begin{array}{c}\text { Not bro- } \\
\text { ken/cracked }\end{array}$ & $\begin{array}{c}\text { Not broken/cracked, } \\
\text { no crack in the edge } \\
\text { area } \leq 50 \mathrm{~mm}\end{array}$ & $\begin{array}{c}\text { Not bro- } \\
\text { ken/cracked }\end{array}$ & $\begin{array}{c}\text { Not bro- } \\
\text { ken/cracked, no } \\
\text { crack in the edge } \\
\text { area } \leq 50 \mathrm{~mm}\end{array}$ \\
\hline
\end{tabular}


clay so that local clay could be recommended as one of the raw materials for cement board production.

\subsection{Surface Morphology of Cement Board}

The results of the surface morphology of cement boards made from kaolin Belitung and imported clay are shown in Figure 1.
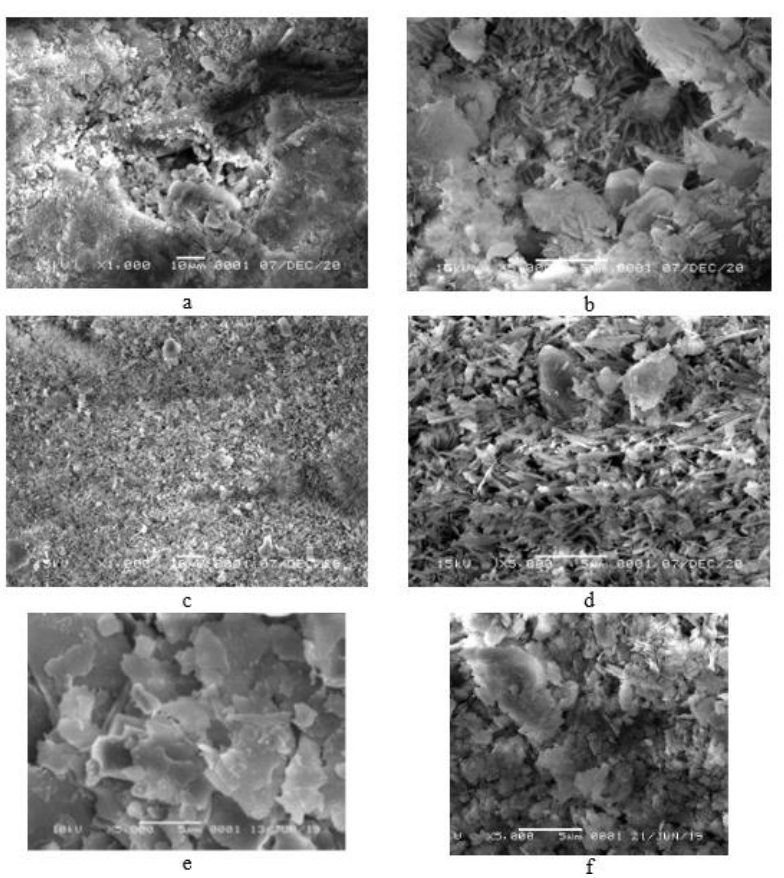

Figure 1 Mikrogram (a) kaolin Belitung cement board enlargement 1000x; (b) kaolin Belitung cement board enlargement 5000x, (c) imported clay cement board enlargement 1000x; (d) imported clay cement board enlargement 5000x; (e) imported clay enlargement 5000x; (f) kaolin Belitung enlargement 5000x.

The results of cement boards microgram made from imported clay showed a higher density than cement boards made from kaolin Belitung. This is in accordance with the characteristics of illite which has a larger surface area and does not agglomerate more easily than kaolin.

\section{CONCLUSION}

In this study, the calcium silicate cement board had been produced using Kaolin Belitung and imported clay. Based on previous research kaolin Belitung is considered the most promising substitute for imported clay. The results revealed that the calcium silicate cement board made from Kaolin Belitung has comparable bending strength $\left(\sim 130,16 \mathrm{~kg} / \mathrm{cm}^{2}\right)$, water absorption $(\sim 13,1 \%)$, and porosity $(\sim 34,7 \%)$. It also gave good results at dimension, waterproof and weather resistance characterization. These properties suggest that Kaolin Belitung may be used as imported clay substitution in the production of calcium silicate cement board.

\section{ACKNOWLEDGMENT}

This research was supported by The Institution of Industrial Research and Standardization Banjarbaru (Balai Riset dan Standardisasi Industri Banjarbaru), Ministry of Industry. The authors would like to thank Mr. Idrus, Mr. Imam and all staf at PT. Sinar Nusantara Industries (SNI), South Kalimantan, for assisting with calcium silicate cement board production and testing. We also would like to thank UIB2T DKI Jakarta and Geology Laboratories PSG for conducting testing.

\section{REFERENCES}

[1] M Chen, L Lu, S Wang, P Zhao, W Zhang, and S Zhang, Construction and Building Materials 143, 280-288 (2017).

[2] L Kristanto, et al., Procedia Engineering 171, 679 688 (2017).

[3] Nurhidayati et all, JKGI 2 December (2020)

[4] IDGP Prabawa et all,

[5] SK S Hossain and P K Roy, boletín de la socie-dad español ade cerámica y vidrio 58, 274-284 (2019). 